\title{
Assessment of onion varieties for late Kharif
}

\author{
S. M. Hiremath* and S. M. Mantur \\ ICAR-Krishi Vigyan Kendra (U.A.S.), INDI, VIJAYAPUR (KARNATAKA) INDIA \\ (Email : hiremathsm10677@uasd.in)
}

\begin{abstract}
Onion (Allium cepa L.) is one of the important commercial vegetable crops grown in India for both domestic consumption and export. India accounts for 16 per cent of the world's area and occupies the second position after Chaina in production with share of around 14 per cent. The production and productivity of onion is mainly depends on location, cultural practices, genotype and environmental factors. In Dharwad district of Karnataka state, onion plays major role in supplementing the income of small and marginal farmers. The productivity of onion in the district is much lower than the state and national average is mainly because of cultivation under rain fed condition, delayed on set of monsoon and non-availability of high yielding varieties particularly to late Kharif season. Hence, in this regard the Krishi Vigyan Kendra, Saidapur Farm, UAS, Dharwad conducted adaptive research on assessment of onion varieties for late Kharif season on farmers fields at Sotakanal, Kadadalli, Ballarawad, Hebballi and Navalagund villages of Dharwad district during 2013-14 and 2014-15. From the study it is revealed that onion variety Bhima Super performed better in both growth and yield parameter compared to Bhima Red, Arka Kalyan and Bellary Red variety. The market preference was more in Bhima Super variety and fetches higher price in the market. Bhima Super variety registered 34.01 per cent increased yield over Bellary Red variety.
\end{abstract}

Key Words : On farm testing, varietal evaluation, Farmers preference

View Point Article : Hiremath, S.M. and Mantur, S.M. (2018). Assessment of onion varieties for late Kharif. Internat. J. agric. Sci., 14 (1) : 102-105, DOI:10.15740/HAS/IJAS/14.1/102-105.

Article History : Received : 08.06.2017; Revised : 14.11.2017; Accepted : 27.11.2017

\footnotetext{
* Author for correspondence:
} 